SEFAD, 2020; (44): 487-508

e-ISSN: 2458-908X

DOI Number: https://doi.org/10.21497/sefad.845489

\title{
Keşifler Çağında Avusturya Kraliyet Doğa Tarihi Müzesi Müdürü Zoolog Franz Steindachner ve Osmanlı Topraklarındaki Araştırmaları
}

\author{
Doç.Dr. Meltem Begüm Saatçı Ata (iD) \\ Akdeniz Üniversitesi, Eğitim Fakültesi \\ Türkçe ve Sosyal Bilimler Ĕ̆itimi Bölümü \\ melbesa@gmail.com
}

Öz

Franz Steindachner 85 yıllık ömrünün dörtte üçünü ihtiyoloji (balık bilimi) alanında özgün araştırmalara adamış bir zoologdur. Avusturya'da alanı ile ilgili farklı kurumlarda görev almıştır. 1898-1919 yılları arasında Avusturya Kraliyet Doğa Tarihi Müzesi müdürlüğü görevini üstlenmiş olan Steindachner, 1890-1898 yılları arasında AvusturyaMacaristan İmparatorluğu desteğiyle Doğu Akdeniz Keşif seferlerini gerçekleştiren ekipte yer almıştır. Aynı kapsamda Balkanlar ve Anadolu topraklarında ihtiyoloji alanında araştırmalar yapmıştır. Steindachner'in Keşifler çağı olarak da kabul edilen 19. yüzyılda Osmanlı Devleti'nde de keşif gezileri olmuştur. Ancak bu bir devlet politikası olmaktan uzak olduğu için bilimsel gelişmelerin öncüsü olamamıştır. Steindachner'in keşif seferleri kapsamında gerçekleştirdiği araştırma gezileri Osmanlı Devleti tarafından engellenmemiştir. Osmanlı Devleti'nin keşifler çağındaki yeri, bir yönüyle zoolog Franz Steindachner'in çalışmaları ile anlaşılabilir. Bu çalışmalar, 1890'lı yıllarda Osmanlı Devleti topraklarının ihtiyoloji alanındaki durumu hakkında bilgi içermektedir. Bugün Türkiye coğrafyasında Steindachner tarafından ad verilmiş endemik türler de mevcuttur.

Anahtar Kelimeler: Franz Steindachner, Osmanlı Devleti, keşif seferleri.

\section{The Zoologist Franz Steindachner, the Director of the Austrian Royal Museum of Natural History, in the Age of Discoveries and His Researches in the Ottoman Lands}

\section{Abstract}

Franz Steindachner is a zoologist who devoted three-quarters of his 85-year life to original research in the ichthyology (fish science). He was assigned for duty in different institutions related to the zoology in Austria. Between the years 1890 and 1898, he took part in the team that carried out Eastern Mediterranean Expeditions with the support of the Austro-Hungarian Empire. From 1898 to 1919, he served as the director of the Austrian Royal Museum of Natural History. In this context, there were also expeditions in the Ottoman Empire in the 19th century and Steindachner made researches in the field of ichthyology in the Balkans and Anatolian lands. These researches were not hindered by the Ottoman Empire. However, the Ottoman Empire has not been a pioneer of scientific developments. The place of the Ottoman Empire in the age of discoveries can be understood by the work of the zoologist Franz Steindachner. His researches included information about the state of the Ottoman Empire's territories about the ichthyology of the 1890's reign. Today, Turkey's endemic advertising given by Steindachner in geography are available.

Keywords: Franz Steindachner, Ottoman State, scientific expeditions. 


\section{GİRIŞ}

19. yüzyıl, doğa bilimlerinde keşiflerin yoğun olarak yaşandığ 1 bir dönemdir. Diğer doğa bilimlerinin deniz araştırmaları ile bütünleştirilmesi olarak da tanımlanabilecek oşinografi (deniz bilimi) alanında bu dönemdeki çalışmalar oşinografinin ayrı bir bilim dalı haline gelmesini sağlamıştır. Bu alandaki çalışmalarında Avusturya-Macaristan İmparatorluğu öncü devletlerden birisi olmuştur. Zoolog Franz Steindachner (11 Kasım 1834-10 Aralık 1919) Avusturya-Macaristan İmparatorluğu'nun farklı kurumları tarafından desteklenen oşinografi çalışmalarında görev almış ünlü bir bilim insanıdır. Doğu Akdeniz ve Kızıl Deniz'deki keşif seferlerine de katılmış olan Steindachner'in Osmanlı Devleti'nin topraklarında da araştırmalar yaptığı bilinmektedir.

Literatür taramasında mevcut çalışmalar arasında oşinografi dalının tarihi gelişimi hakkında bilgi bulmak mümkündür. Bununla birlikte Franz Steindachner'in özellikle Doğu Akdeniz ve Kızıl Deniz'de yapılan keşif seferlerindeki katkısı ile ilgili bilgiye erişmek de mümkündür. Ancak Osmanlı Devleti topraklarında Anadolu ve Balkanlardaki araştırma girişimleri ve bu araştırma sonuçları ile ilgili yapılmış bir araştırma mevcut değildir.

Bu çalışmada Franz Steindachner'in hayatı ve bilimsel çalışmaları ile ilgili bilgiler içeren kaynaklar arasında, kapsamı geniş iki yayın mevcuttur. İlk olarak Günther Schefbeck'in 1996'da yayınlamış olduğu "The Austro-Hungarian Deep-Sea Expeditions" adlı makalesi, oşinografi bilim dalının kısa tarihçesinin yanı sıra Franz Steindachner'ın oşinografi bilim dalına katkıları ile onun Doğu Akdeniz ve Kızıl Deniz'deki araştırmalarda üstlendiği rolü ortaya koyan önemli bir çalışmadır. Ancak bu eserin bu makale çalışması çerçevesinde en önemli eksiği Osmanlı Devleti ile ilişkilendirmede eksik ve kimi zaman yanlış değerlendirmeler içermesidir. İkinci önemli yayın ise Von Paul Kähsbauer'in Doğa Tarihi Müzesi Yıllığında Franz Steindachner'in ölümünün 40. yılında, 1959'da yazmış olduğu Biographisches, Intendant Dr. Franz Steindachner, sein Leben und Werk adlı eseridir. Bu yayın, Steindachner'in hayatı ve bilimsel çalışmalarını, ulaşılan kaynaklar arasında en ayrıntılı ele almış olandır. Ancak bu çalışmanın da en önemli eksiği Osmanlı Devleti'nin Franz Steindachner'in çalışmalarını nasıl yönlendirdiği ve etkilediği konusudur.

Bu makalenin en önemli kaynak grubu Osmanlı Devleti'nin konu ile ilgili kayıtlarıdır. Franz Steindachner'in 1890'l1 yıllarda Anadolu ve Balkanlarda bulunduğu bilinmektedir. Ulaşılabilen Osmanlı Devleti arşiv belgeleri arasında doğrudan Steindachner'in Anadolu ve Balkanlardaki araştırmaları ile ilgili olan veya onun bu bölgelerdeki araştırmalarını değerlendirmeye yarayan belgelerin en eski tarihlisi 1891 yılına aittir. 1890'larda yoğunlaşan belgeler dışında ulaşılabilen ve konu ile dolaylı yoldan ilgili olan 20. yüzyıl başına ait çok sayıda belge mevcuttur.

\section{KEŞİFLER ÇAĞINDA İKI DEVLET İKİ ÖRNEK}

\section{Keşifler Çağında Avusturya (-Macaristan) İmparatorluğu}

Avusturya'da yönetim şekli 1806 yılında Arşidüklükten İmparatorluk haline dönüşerek Avusturya İmparatorluğu; 1867 yılında ise Avusturya-Macaristan İmparatorluğu idari şekliyle siyasi varlığına devam etmiştir. Devletler arasında güç dengelerinin yenilendiği bu dönemde siyasi kararlarda varlığı devam etse de Avusturya (-Macaristan) İmparatorluğu'nun artık karar verici başat güç olmadığı aşikardı. Bununla birlikte siyasi alan dışındaki bilimsel ve kültürel faaliyetlerde etkisini devam ettirmiştir. Avusturya (Macaristan) İmparatorluğu'nun bu çağın başından itibaren keşifler çağı ifadesinin hakkını 
verecek önemli keşif seferlerini başlattığı bilinmektedir. Bunlardan ilki olarak, daha yüzyılın başında, Avrupa Devletleri arasında 1815 tarihli Viyana Kongresinde alınan kararlar uyarınca siyasi dengeler kurulmaya veya korunmaya çalışılırken, aslında siyasi dengeden daha belirleyici olacak olan bilimsel çalışmalardaki dengeyi ilgilendiren gelişmeler tarihe geçmiştir. Bu çalışmaların ilki 1817-1835 yılları arasında gerçekleştirilen Brezilya yağmur ormanlarındaki keşif seferleridir. Bu seferin başlamasını kolaylaştıran unsur Avusturya arşidüşesi Leopoldina'nın (1797-1826) ileride Brezilya'nın ilk kralı olacak olan Dom Pedro (1798-1834) ile evlenmesi olmuş görünmektedir. Ama sonuç itibariyle bu keşif seferi Avusturya İmparatorluğu Doğa Tarihi Müzesi Koleksiyonunun böcek, bitki, kuş vb alanlarda zenginleşmesini de sağlamıştır (Christian, 2013-2014a, s.61; Christian, 2013-2014b, s.1).

İkincisi 1857-1859 yılları arasında iki yıl kadar sürmüş olan Avusturya Bilimler Akademisi ve Coğrafya Derneği'nin öncülüğünde gerçekleşmiş olan keşif çalışmalarıdır. Coğrafi amaçlı başlayan ve 1843-1899 yılları arasında hizmet görmüş olan Novara (Organ, 2007, 10 Nisan) isimli Avusturya firkateyni ile çıkılan bu yolculukta bilim adamlarının amacı daha önce keşfedilmemiş uzak kıyılarda araştırma yapmak olmuştu (Schefbeck, 1996, s. 4). Trieste'den çıkan Novara Cebelitarık Boğazı'nı geçip Güney Afrika'yı dolaşarak Singapur, Cakarta, Hong Kong, ardından Avustralya ve ardından Güney Amerika üzerinden yeniden Trieste'ye varmıştır ("Novara Expedition”, t.y.). Bir başka deyişle, Novara ile bilimsel keşif amaçlı bir dünya turu yapılmıştır. 1880'lerde İngiltere ve diğer devletlerin de bu tür araştırma keşif seferlerine dâhil olması ile oşinografi (deniz bilimi) alanındaki gelişmişlik seviyesi bu devletler arasında bir güç göstergesi haline gelmeye başlamıştır. Bu nedenle, oşinografi alanındaki bu rekabet bağlamında Franz Steindachner'in bilimsel çalışmalarının rolü daha önem kazanmaktadır. Steindachner'in çalışmaları, dört aşamaya bölünmüş olan oşinografi tarihinin özellikle ilk aşaması veya keşif aşaması kabul edilen 1873-1914 yılları arasında yoğunlaşmıştır (1. aşama 1873-1914, 2. aşama 1914 sonrası-1939, 3. aşama 1945 sonrası-1957 ve 4. aşama 1957 sonrası.) (Schefbeck, 1996, s. 5).

Avusturya-Macaristan İmparatorluğu tarafından 19. yüzyılda gerçekleştirilmiş olan keşif seferlerinin üçüncü önemli örneği 1872-1874 yılları arasındaki, adını Avusturyalı Amiral Wilhelm von Tegetthoff'tan almış olan Kuzey Kutbu keşif seferidir (Schimanski ve Spring, 2009, s. 50-76). Bu keşif seferlerindeki alt yapı çalışmaları da öncelikli alanlar arasında olmuştur. Bilimsel çalışmalar sadece yeni yerler keşfetmekle değil, aynı zamanda bilimsel çalışma yöntemlerinin geliştirilmesiyle ilerleyebilmiştir. 1874'te Alman bilim adamı Anton Dhorn (1840-1909) tarafından Napoli'de, bugün de adıyla anılan Deniz Biyoloji İstasyonu kurulmuştur. Bundan kısa bir süre sonra 1875 yllında bu alandaki öncüler arasinda olan bir biyoloji istasyonu da Viyana Üniversitesinden Carl Claus (1835-1899) ve Graz Üniversitesinden Franz Eilhard Schulze (1840-1921) tarafından Trieste'de kurulmuştur (Schefbeck, 1996, s. 3). Franz Steindachner'in 1890'lı yıllarda Osmanlı Devleti topraklarındaki araştırma seferlerini de kapsayan keşif hareketi ise Avusturya-Macaristan'ın 19. yüzyılda gerçekleştirdiği yeni bir harekettir. İşte Avusturya-Macaristan İmparatorluğu tarafından desteklenen ve Steindachner'in çalışma alanını da ilgilendiren bu istasyonlar bilim adamlarının çalışma yöntemlerini geliştirmelerine yardımcı olmuştur.

\section{Osmanlı Devleti ve 19. Yüzyıl Keşifler Çağındaki Yeri}

Osmanlı Devleti toprakları, 19. yüzyılda bilim adamları ve her ne nedenle olursa olsun bilimsel çalışmaları destekleyen devletlerin bilimsel keşifleri için cazip bölgelerden 
birisi olmuştur. Bu cazibenin nedeni bölgenin bilimsel keşifler için zenginliği olduğu gibi devletlerarası dengede nüfuz alanlarını genişletmek isteyen devletlerin Osmanlı Devleti topraklarını da içine alan bölgenin ekonomik zenginlik ve stratejik güç potansiyeli olmuştur. Seyyahlar, misyonerler gibi bilim adamları da bu amaç için çalışanlar arasında olmuştur. Bilimler arasında arkeoloji ilk akla gelen olmakla beraber biyoloji, botanik, zooloji, kimya, meteoroloji gibi bilim dalları da bu bölge üzerinde çalışmaların yoğunlaşmasına neden olmuştur.

Bu cazibe birçok bilim adamı ve kâşifi bu topraklara çekerken 19. yüzyılda bu topraklardan da dünyaya açlan örnekler az sayıda da olsa mevcuttu. Ancak bunların amacının bilimsel bir keşiften ziyade devlet örgütünün Batılı ülkeler karşısındaki geri kalmışlığına çözüm arama çabaları çerçevesinde olduğu görülmektedir. Bu ise, ağırlıklı olarak ordu yapılanmasıyla ilgili olmakla beraber doğa bilimlerinin dallarını da kapsayan bilgileri de içermiştir. Avrupalı araştırmacılarla Osmanlı araştırmacıları arasındaki farkı görmek için iki farklı seyahat örnek olarak gösterilebilir. Bunlardan bir tanesi 1865 yılının Eylül ayında İstanbul'dan hareket edip Basra'ya gitmek ile görevlendirilmiş olan Bursa ve İzmir adlı iki Osmanlı savaş gemisi ile yapılan seyahattir. Ancak bu seyahatin rotası, istenmeden de olsa, planlananın dışına çıkmış ve Brezilya, Afrika kıyıları ile Hindistan'a uğradıktan sonra ancak Basra'ya varabilmiştir. Bu seyahatte Bursa adlı gemide Mühendis Faik Bey de görevlidir. Faik Bey eserinde (Mühendis Faik, 1868), Steindachner veya benzeri bilim adamlarının araştırma amaçlarına benzer amaçla olmasa da, örneğin Brezilya coğrafyası, doğa yapısı, altın, elmas gibi madenleri, ormanları, bitki çeşitliliği gibi konulara dair bilgileri kaleme almıştır (Asiltürk, 2009, s. 960).

İkinci olarak ise yüzyılın sonuna doğru, Steindachner'in Osmanlı topraklarında bulunduğu zaman dilimi ile örtüşen bir örnek kullanılabilir. 1894 yılında Hudeyde'de memur olarak göreve başlamış olan Doktor İbrahim Abdüsselam Paşa'nın Yemen'de yaptığ1 araştırmalarda Yemen coğrafyası ve bitki örtüsü ile ilgili bilgileri aktarması bu dönemde Osmanlılarda doğa bilimlerinin, örneğin botanik biliminin öneminin farkında olunduğunu gösterse de bu devlet politikası olmaktan uzak kalmışır. Doktor İbrahim Abdüsselam Paşa'nın kendi ifadesiyle 'coğrafya ve doğa tarihi gibi, medeni toplumların ilerlemesinin biricik sebebi olan bir şey' (Doktor İbrahim Abdüsselam Paşa, 2008) olarak ifade edilen bu çalışmalarda Osmanlı Devleti önder olmaktan uzak ancak takipçi seviyesinde kalmıştır.

$\mathrm{Bu}$ araştırmanın konusu, Osmanlı topraklarında doğa bilimleri üzerine yapılan keşif seferleri arasında Franz Steindachner tarafından yapılanlar ve bununla ilgili gelişmelerdir. Osmanlı yönetiminin Steindachner ile ilgili tutumunda sayıları ve etkileri az olsa da yukarıda değinilen bu örneklerin de etkisi olduğu düşünülebilir. Bu örnekler, Osmanlı Devleti'nin kendisini bilimsel gelişmelere kapalı tutmadığını, fakat ancak bu kadarını yapabildiğini belirtmek üzere verilmiştir. Gelişmelerin önünü kısmen tıkayan veya yeterince açamayan nedenler arasında elbette ekonomik olduğu kadar Osmanlı Devleti'nin iç ve dış özellikle siyasi ve ekonomik ilişkilerde yaşadığı sorunlar da etkili olmuştur. 19. yüzyılda Osmanlı Devleti topraklarında farklı bilim alanlarında çalışma yapanların takip altında tutulmaya çalışıldığı arşiv belgelerinden anlaşılmaktadır. Ancak Osmanlı Devleti kurumları bu araştırmacılarla ilişkilerinde, kimi zaman istemeseler de bu araştırmaları destekleyen devletlerin baskısıyla, onlara araştırma izinlerini verdikleri örnekler de mevcuttur. Osmanlı idarecilerinin, bu araştırmacıların amaçları dışında hareket etme durumunda onların kendi devletlerinden aldıkları destek karşısında etkin karar veremedikleri durumlar da olmuştur. 
Bu da, Osmanlı Devleti'nin devletlerarası dengedeki güçsüzlüğünden dolayı onun kendi topraklarındaki yabancı araştırmacıların denetimini de zora soktuğunu göstermektedir.

Tüm bu gelişmelerle beraber Osmanlı Devleti'nin keşifler çağındaki konumunu ortaya koyan daha belirleyici bir durum da vardır. Bu da, Avrupa'da keşif hareketlerine öncülük eden bilim akademilerinin Osmanlı Devleti'nde kurulması düşüncesinin ancak 19. yüzyılın ortalarında gündeme gelebilmiş olmasıdır. Kendi içinde bir ilerleme olsa da Encümen-i Daniş (1851), Cemiyet-i İlmiye-yi Osmaniye (1861) veya Cemiyet-i İlmiye (1879) gibi girişimler Avrupalı devletler tarafından yürütülen ve buralardaki bilim akademileri tarafından desteklenen keşif hareketlerine dahil olabilecek kadar kapsamlı, programlı ve sürdürülebilir işler yapamamışlardır (Elmacı, 2017, s. 91; İhsanoğlu, 1987, s. 4, 19).

Franz Steindachner'in 1890'lı yıllarda Osmanlı Devleti topraklarında araştırmalarına başlamadan önce de bu topraklara gelmiş olan diğer Avrupalı devletler gibi Avusturyalı bilim adamlarının da varlığı bilinmektedir. Örneğin 1887 yılında, yani Doktor İbrahim Abdüsselam Paşa'nın Yemen'deki araştırmalarından yaklaşık 7 yıl önce, Viyana Rasadhanesi eski muallimi Mösyö Galazar'ın 'bazı fenni incelemelerde bulunmak üzere' Yemen'e gideceği bilgisi Yemen Vilayetine bildirilmiştir (BOA, DH.MKT., 1445/104, H. 22.12.1304/11 Eylül 1887). Bir başka örnek de Haziran 1890'da Avusturya Viyana Maden Mektebi muallimlerinden Mösyö Franç Tolanik'in Rumeli topraklarında 'ilm-i tabakatü'larz'a yani jeoloji bilimine dair yapacağı araştırmalar esnasında kendisine yardımcı olunması konusundaki Osmanlı yetkililerinin talimatıdır (BOA, MH.MKT., 1728/16, H. 13.10.1307/2 Haziran 1890). Bu iki örnek ve benzerleri bir yandan Franz Steindachner'in bölgedeki araştırmalarında, özellikle Osmanlı resmi makamları ile kuracağı iletişimde kendilerine yardımcı olma hususunda, diğer taraftan, Osmanlı Devleti yetkililerinin de bu araştırmacıları takibinde örnek teşkil etmiş olması açısından mühimdir. Bununla beraber, 19. yüzyıl sonu-ve 20. yüzyıl başında öncelikli sorunu bilimsel faaliyetlerden ziyade siyasi var olma mücadelesi olan Osmanlı Devleti'nin Franz Steindachner'in çalışmalarına verdiği tepki de bu bağlamdan bağımsız düşünülemez.

\section{Steindachner'ın Hayatı ve Bilimsel Faaliyetleri}

Franz Steindachner 11 Kasım 1834'te Viyana'da doğmuştur. Babası Rosaenfeld'den Doktor Franz Xaver Steindachner (1802-?), annesi ise Viyana'lı Anna Grienauer'dır(1803-?). Anna ve Barbara adlarında iki kız kardeşi olan Steindachner hiç evlenmemiştir. Viyana Üniversitesinde hukuk öğrenimine başlayan Steindachner, bu fakültedeki öğrenimini bırakıp doğa bilimlerinde öğrenimine devamla, ihtiyoloji alanına yönelmiştir. 1857'den itibaren bu alanda çalışmalarını yoğunlaştırmış ve 1857 'de Viyana'da henüz öğrenciliği devam ederken Zooloji ve Botanik Derneğine üye olmuştur ("Steindachner, Franz", 2013). Daha sonra ise aynı derneğin yönetim kadrosunda yer almış ve 1900 yılına kadar dernek üyeliği etkin olarak devam etmiştir. Bu süreçte eserleri Avusturya Bilimler Akademisi ve Avusturya Kraliyet Doğa Tarihi Müzesi yayınları arasında çıkmaya başlamıştır (Kähsbauer, 1959, 26 Ağustos, s. 1-2). Zoolojinin bir alt birim olan ihtiyoloji alanında uzmanlaşmış olan Franz Steindachner, Profesör Rudolf Kiner (1810-1869)'in Giovanni Canastrini (1835-1900) ile birlikte 1857-1859 yılları arasında Novara adlı firkateyn ile yapmış oldukları araştırmalarda elde ettikleri balıkların incelenmesi için davet edilmiştir ("Franz Steindachner 1834-1919", t.y.). 1857 yılı sonrasinda, Steindachner'in öğrencisi olduğu Prof. Dr. Rudolf Kiner'in Avusturya'nın Novara ile başlattığı keşif seferine davet edilmiş olması (Salvini-Plawen ve 
Svotjka, 2008, s. 91) Steindachner'in ilerideki çalışmalarını ve elbette bunlar arasında Osmanlı Devleti'ne yönelmesini de etkilemiş olmalıdır.

1860 yılında Avusturya Kraliyet Doğa Tarihi Müzesi Zooloji Bölümünde İhtiyoloji çalışmalarından sorumlu görevli olarak çalışmaya başlayan Steindachner ("Franz Steindachner 1834-1919", t.y.), 1861 yaz aylarında Dalmaçya'da keşif seferine katılmıştır. Steindachner bundan sonra İhtiyoloji gibi Herpetoloji (Sürüngen ve Amfibi Bilimi) Bölümleri koleksiyonundan da sorumlu; 1867 yllında Kraliyet Bilimler Akademisi fahri üyesi (Kähsbauer, 1959, s. 9) ve Mart 1869'da ise Zooloji Bölümün en deneyimli kişisi olduğu için, bölümün yetkilisi olarak atanmıştır. 1896 yılında Amerikan Ulusal Müzeleri ile ilgili hazırlanmış olan raporda, onun Avusturya Kraliyet Doğa Tarihi Müzesinde Zooloji Bölümünün sorumlusu olduğu belirtilmiş (Annual Report, 1898, s. 25) ve 1870'li yıllarda Harvard'da Louis Agassiz ve ekibiyle birlikte çalışmıştır. Steindachner 1870 yılında açı denizlerde araştırma yapmayı planlayan Prof. Louis Agassiz'in daveti ile Boston yakınlarında Cambridge'de çalışmaya katılmıştır (Stagl, 2008, s. 164). Aralık 1871-Ağustos 1872 tarihleri arasında Güney Amerika'da yapılan bu araştırma seferinde Steindachner Avusturya Kraliyet Doğa Tarihi Müze koleksiyonunu zenginleştirecek materyal toplamıştır. Yaklaşık 45 ay sonra ise Ocak 1874'te yeniden Viyana'ya dönmüş olan Steindachner, 1875 yılında Kraliyet Bilimler Akademisi asli üyesi olmuştur (Kähsbauer, 1959, s.2-5, 9).

Şubat 1876'da Avusturya Kraliyet Doğa Tarihi Müzesi Zooloji Bölümünün yöneticiliğini üstlenmiş olan Steindachner, Avrupa'da alanı ile alakalı bilimsel amaçlı 3 gezi düzenlemiştir. Bu kapsamda 1877'de İngiltere, 1881'de Dalmaçya ve Karadağ, ardından 1883 'te Londra, Paris, Marsilya, Nice ve Cenova'da bulunmuştur. Bu gezileri sonrasında Zooloji Bölümü koleksiyonunun artmış olması, müze binasının Josefplatz'dan Burgring'de yeni bir binaya taşınmasını sağlamıştır. Ocak 1884 tarihinde Hükümette Meclis Üyesi olmuş olan Steindachner Ocak 1886 'da ise ihtiyoloji ve herpetoloji koleksiyonunda bulunan eserlerin Avusturya Kraliyet Doğa Tarihi Müzesi binasına taşınmasına öncülük etmiştir (Kähsbauer, 1959, s. 5-6). Uluslararası işbirliği içindeki çalışmalarına devam eden Steindachner, bir dönem Strassburg Zooloji Müzesi sorumluluğunu da üstlenmiş olan Dr. Ludwig Heinrich Philipp Döderlein'ın (1855-1936) 1879-1881 yılları arasında Japonya'daki araştırmalar sonucu topladığı balık türlerine birlikte isim vermiş ve bu çalışma Avusturya Bilimler Akademisi'nin 1883-1887 yılları arasındaki tutanaklarında yer almıştır (Nature, 1936, s. 808). Ağustos 1889 tarihinde Kraliyet Meclis Üyesi olan Steindachner aynı yıl Kraliyet Bilimler Akademisi Oşinografi Araştırmaları Komisyonu Başkanı olmuştur (Kähsbauer, 1959, s.9).

\section{Avusturya-Macaristan İmparatorluğu'nun Keşifler Çağı ve Franz Steindachner'in} Katkıları

Avusturya(-Macaristan) İmparatorluğu'nun ilk olarak 1817 yılında Brezilya yağmur ormanlarında başlayarak öncülük ettiği keşif seferlerinde, özellikle 19. yüzyıl sonlarına kadar asıl yükü, Donanma'nın sağladığı destek taşımıştır (Schefbeck, 1996, s. 7). Bu dönemde siyasi olarak ikinci plana düşme eğilimine giren Avusturya-Macaristan İmparatorluğu, örneğin Doğu Akdeniz'de siyasi, ekonomik ve askeri nüfuz alanını genişletme yarışında etkin olan öncelikle İngiltere ve ardından Rusya, Fransa, ne kadar giderek zayıflasa da İtalya ve giderek sesini duyuracak olan Amerika Birleşik Devletlerinin gerisinde kalmaya başlamıştır (Erbaş, 2016, s. 135-136). Ancak Avusturya-Macaristan İmparatorluğu, bu yarıştaki çabalar dışında bilimsel keşif seferlerine ağırlık vermiştir. 
Avusturya-Macaristan İmparatorluğu'nun bu keşif seferlerinde Donanma dışında üç kurum etkin rol almıştır. Bunlar Kraliyet Bilimler Akademisi, Avusturya Kraliyet Doğa Tarihi Müzesi ve Viyana Üniversitesi Zooloji ve Kimya Bölümleri idi. Deniz araştırmaları bu keşif seferlerinde yeni ve önemli bir bilim dalı olmuştur. 19. yüzyılın bir ürünü olarak ortaya çıkan oşinografi bilim dalı, diğer bilim dallarının deniz araştırmalarında kullanılmasıyla gelişim göstermiştir. Özellikle biyoloji bilimi, deniz araştırmalarında öncelikli ilişkili çalışma alanı olmuştur. Örneğin Charles Robert Darwin'in (1809-1882) Evrim Teorisi deniz bilimleri çalışmalarının olduğu gibi, Avusturya Açık Deniz Keşif seferlerinin seyrini de etkilemiştir. Bu bağlamda Avusturya-Macaristan İmparatorluğu'na ait ilk Deniz Zooloji İstasyonunun 1875 yılında Trieste'de Carl Claus ve Franz Eilhard Schulze tarafından kurulması akla gelebilecek ilk örnektir. Kuruluşundan itibaren uzun zaman diliminde farklı bilim dallarında Trieste'deki bu istasyonda, örneğin aralarında yılan balığı yumurtaları üzerine çalışmalar yapan Sigmund Freud'un (1856-1939) da bulunduğu bilim adamları arasında bu dönemde Franz Steindachner de yer almıştır (Schefbeck, 1996, s. 1-4, 8).

19. yüzyılda artık bir ulusal itibar göstergesi olan oşinografi alanında AvusturyaMacaristan İmparatorluğu'nun önemli girişimleri olmuştur. Bilimsel çalışmalarda disiplinler arası yaklaşımın geçerli olmaya başladığı bu dönemde devletlerarası işbirliği de gündeme gelmiştir. Örneğin 1910 yılında Akdeniz Bilimsel Keşifler Uluslararası Komisyonu kurulması (Schefbeck, 1996, s. 4, 6) bu bağlamda değerlendirilebilecek bir gelişmedir. Ancak bundan önce devletler kendi çabalarını geliştirecek girişimlerde bulunmuşlardır. 1867 yılında Viyana'da Avusturya Bilimler Akademisi tarafından 'Adriyatik Denizi Fiziki Zenginliklerini Araştırma Komisyonun' kurulması bunun için önemlidir. Bu Komisyon 1880 yılına kadar çalışmış ve yürütülen araştırmalar ile ilgili yayınlar yapmıştır (Schefbeck, 1996, s. 7).

\section{Steindachner ve Osmanlı Devleti Topraklarındaki Faaliyetleri}

1896-1897 yılları arasında vekâleten, 1898 yılından 1919 yılında ölümüne kadar geçen sürede ise asaleten Avusturya Kraliyet Doğa Tarihi Müzesi müdürü olarak görev yapmış olan zoolog Franz Steindachner'ın ("Franz Steindachner 1834-1919", t.y.) Osmanlı Devleti topraklarındaki ilk inceleme gezisinin Balkanlarda olduğu bilinmektedir. Ancak arşiv belgelerinde Franz Steindachner'i adı ile takip etmek her zaman mümkün değildir. Dil farkından dolayı adı farklı şekilde yazılmıştır. Bu durum araştırmada iz sürmeyi zorlaştırsa da ilgili yılları kapsayan belgelerde içerik taraması ile konuyla ilgili belgelere ulaşmak ancak mümkün olmuştur. Dil farklılığından dolayı Osmanlı devlet görevlileri tarafından adı Firenc İstaindahz, Franç İştaidahz, Franç Estaind Ahzen, Kranç Estain Dahter veya Franc Eştandahtar gibi farklı şekillerde yazılmış olan Franz Steindachner, Osmanlı Devleti kayıtlarında Viyana Müzesi müdürü, Viyana Müzesi hayvanat kısmı müdürü ve Viyana Cemiyet-i Fenniye üyesi (BOA, BEO, 280/20955, H. 13.03.1311/24 Eylül 1893) olarak zikredilmiştir.

Doğu Akdeniz keşif seferleri: 19. yüzyılda önemli keşif seferlerini planladığı, desteklediği, yürüttüğü bilinen Avusturya Bilimler Akademisi, 1890'lı yıllarda AvusturyaMacaristan İmparatorluğu'nun gerçekleştirdiği Akdeniz ve Kızıl Deniz'deki keşif seferlerini de desteklemiştir. Bu kurumun yanı sıra Avusturya Kraliyet Doğa Tarihi Müzesi ve Viyana Üniversitesi de bu keşiflerin destekçisi olmuştur. Franz Steindachner'in bu üç kurum ile de bağlantısı vardı. Steindachner, muhtelif zamanlarda ve sürelerle Avusturya Bilimler Akademisi üyesi, Avusturya Kraliyet Doğa Tarihi Müzesi çalışanı ve müdürü, Viyana Üniversitesi üyesi görevlerini ifa etmiştir.

SEFAD, 2020; (44): 487-508 
11 Nisan 1889'da Avusturya Açık-Deniz Araştırmaları kapsamında Doğu Akdeniz'de yapılacak araştırma için, başını Avusturya Kraliyet Doğa Tarihi Müze müdürü zoolog Franz Steindachner ile jeolog Franz Ritter von Hauer (1822-1899) ve meteorolog Julius Hann'ın (1839-1921) çektiği üç kişilik ekip tarafından Avusturya Bilimler Akademisi'ne bir öneri verilmiştir. Bu öneriyi dikkate alan Avusturya-Macaristan Devleti; 1890-1894 yılları arasında Doğu Akdeniz, 1895-1896 yılları arasında Kızıl Deniz kuzeyi ve 1897-1898 yılları arasında Kızıl Deniz güneyinde keşif seferleri yapmıştır. Steindachner ve ekibinin bu önerisinde, 1889 yılının Mayıs-Ekim ayları boyunca Paris'teki Dünya Sergisinde, Monaco Prensi Albert (18481922) ile kendisinin Batı Akdeniz'de yapmış olduğu keşif seferleri hakkındaki görüşmelerinin de (Schefbeck, 1996, s. 10, 12) etkisi olduğu düşünülmektedir. Kendisi de oşinografi üzerine yayınlar yapmış ("ESSA Libraraies", 1969, s. 281-282) ve 1889'da tahta çıkmış olan I. Albert'in 1899'da Monaco Oşinografi Müzesini kurduğu düşünülürse Steindachner'i de etkilemiş olması daha anlaşılır olacaktır.

Bu keşif seferlerinde Viyana Üniversitesi ve Avusturya Kraliyet Doğa Tarihi Müzesi birlikte çalışmı̧̧ır. Kraliyet Bilimler Akademisi ise Açık Deniz Komisyonu ile birlikte bu işin bilimsel programının sorumluluğunu üstlenmiştir. 1890'daki ilk keşif seferinde 2 zoolog, Karl Grobben (1854-1945) ve Emil von Marenzeller (1845-1918); 1 kimyac1, Konrad Natterer (1860-1901) ve 1 deniz fizikçisi, Josef Luksch (1836-1901) yer almıştır. Natterer ve Lucksch Avusturya Açık Deniz Keşiflerinin sonuna kadar bu ekipte kalmıştır. Steindachner ise Prag'da Alman Üniversitesinde zoolog olan Berthold Hatschek (1854-1941) ile birlikte 1891'de bu ekibin bilim kurulunda yer almıştır (Svatek, 2014, s. 117-118).

\section{Steindachner'in Doğu Akdeniz Keşif Seferleri Kapsamında Balkanlar Ve Anadolu'daki Araştırmaları}

10 Ağustos 1890 tarihinde birinci Doğu Akdeniz Keşif seferi kapsamında Pula (Bula) limanından ayrılan Pola adlı gemi, Adriyatik Denizi'nden sonra İyonya Denizi'ne ulaşmıştır. Buradaki adalara uğradıktan sonra en güneydeki Çuha (Cerigo/Kithira) adasından ayrılıp Libya sahillerine varmıştır. Burada Ras al Hilal'e ulaşmış olan Pola, Bingazi'ye kadar uzanmış ve buradan İyonya Denizi'ne ulaştıktan sonra 16 Eylül 1890 tarihinde Pula limanı son durağı olmuştur. Bu Doğu Akdeniz'deki ilk keşif seferi, fizik ve kimya araştırmaları açısından biyoloji alanına göre daha verimli geçmiştir. Pola adlı gemide denizciler ile zooloji bilim adamları arasındaki sorunların çözümü için bir görev değişimine gidilmiş ve biyoloji çalışmalarının ilerleyebilmesi için Steindachner bilim ekibinin en yetkili sorumlusu olarak göreve devam etmiştir (Schefbeck, 1996, s. 12-13).

Franz Steindachner'in Temmuz-Eylül 1891 tarihleri arasında gerçekleşmiş olan ikinci Avusturya Açık Deniz Seferi kapsamında Balkanlarda araştırma yaptığı kayıtlarda mevcuttur (Kähsbauer, 1959, s. 6). 1891'de Doğu Akdeniz'e yapılan ikinci keşif amaçlı seyahati 22 Temmuz 1891 ile 9 Eylül 1891 tarihleri arasında yapılmıştır. Steindachner'in Girit, İskenderiye, Mısır sahillerindeki keşif seferi yine Girit üzerinden dönerek Pire limanında sonlanmıştı Osmanlı Devleti arşiv kayıtlarında 25 Ağustos 1891 tarihli belgeden anlaşıldığ1 üzere Girit'in Bula limanında sonlanmış olan (BOA, Y.PRK.ASK., 75/8, H. 19.01.1309/25 Ağustos 1891) bu keşif seferinin uzantısı olarak kabul edilebilecek araştırmalara devam eden Steindachner birkaç ay Balkanlarda bulunmuştur. Kuzey Ege ve Arnavutluk kıyılarında geçen bu gezide Steindachner, Makedonya göllerinde, Avusturya Kraliyet Doğa Tarihi Müzesindeki ihtiyoloji ile ilgili koleksiyonu zenginleştirme fırsatı bulmuştur (Schefbeck, 1996, s. 14). Pire limanı, Ayvasıl, Doyran, Amatovo, Ohri, Küçük 
Prespa (Ventrok) ve Prespa gölleri araştırma alanları arasında yer almıştır. Araştırma ekibi bundan sonra Selanik ve Manastır üzerinden Üsküb'e gitmiştir. Kış aylarının gelmesiyle Kasım 1891 tarihinde Belgrad ve Budapeşte üzerinden Viyana'ya dönülmüştür (Kähsbauer, 1959, s. 6).

1892'de Avusturya Üçüncü Açık Deniz Seferi için Doğu Akdeniz'de araştırma yapmış olan Franz Steindachner bu kez Preveze'den Yenice'ye kadar olan Arnavutluk bölgesinde ihtiyoloji alanında incelemelerde bulunmuştur (Kähsbauer, 1959, s. 6). 1892 ve 1893 keşif seferlerinde Steindachner ekibin tek zooloji uzmanı olarak görevi üstlenmiştir. Avusturya Açı Deniz Keşif seferi öneri sahibi de olan Steindachner bundan sonra ekibin tek zooloji uzmanı olmak dışında keşif seferlerinin bilimsel sonuçlarının tek sorumlu kişisi haline gelmiştir (Schefbeck, 1996, s. 12,14). 16 Ağustos 1892'de başlayan üçüncü Doğu Akdeniz Keşif seferi, Girit'in güneyinden İskenderiye'ye uzanan hat ile Nil deltası ve Filistin, Suriye kıyıları, Kıbrıs kanalı ve Karaman Denizi olarak adlandırdığı Anadolu'nun güneyini de içine alan bir coğrafyayı kapsamıştır. Bu seferde Fethiye körfezinde 3591 metre derinliğe kadar inilebilmiştir. Steindachner'in tek zoolog olarak katılmış olduğu 3. Keşif seferi 22 Ekim 1892'de Rodos'tan sonra Pula limanında son bulmuştur (Schefbeck, 1996, s. 14).

Franz Steindachner'in bilimsel faaliyetleri ile ilgili çalışmalarda, onun Osmanlı Devleti topraklarında yapmak istediği araştırmalarda engel ile karşılaştığını iddia eden örnekler mevcuttur (Schefbeck, 1996, s. 14). Ancak bu iddiadaki yanlışlığı ortaya koyan çok sayıda arşiv belgesi mevcuttur. Örneğin üçüncü Açık Deniz Keşif seferi başlamadan önce Franz Steindachner'in Osmanlı Devleti yetkililerine bölgede araştırma yapmak için başvurduğu anlaşılmaktadır. 28 Temmuz 1892 tarihli belgeden edinilen bilgiye göre, Yanya vilayetinde böcekler ve balıklar ile ilgili inceleme yapma isteğine izin verilmiş olan Franz Steindachner'a yardımcı olunması istenmiştir (BOA, DH.MKT., 1979/58, H. 03.01.1310/M. 28 Temmuz 1892). Franz Steindachner daha ilk girişiminde Osmanlı yönetimi tarafından olumlu karşılandığına göre Schefbeck'in ifade etmiş olduğu Steindachner'in çalışmalarının Osmanlı yöneticileri tarafından engellenmek istediği bilgisi bu dönem için geçerli değildir. Ancak ilerleyen zamanda Osmanlı Devleti'nin Franz Steindachner'ın faaliyetlerine verdiği tepki, dönemin Doğu Akdeniz ve Kuzey Afrika, özellikle Kızıl Deniz ile ilgili konularında devletlerarası ilişkiler bağlamı da göz önünde tutularak değerlendirilmelidir. Franz Steindachner'in Osmanlı Devleti topraklarındaki inceleme gezileri öncelikle Balkan topraklarında devam etmiştir. Bu dönemde Osmanlı Devleti topraklarında Avrupalı bilim adamları tarafından yürütülen arkeoloji, antropoloji veya yeni gelişmekte olan farklı bilim dallarındaki çalışmaların devletler tarafından siyasi bilgi kaynağı olarak da kullanıldığı düşünülürse Osmanlı yönetiminin temkinli tutumu daha iyi anlaşılacaktır. Steindachner ile ilgili doğrudan şüpheli bir durum arşiv belgelerinde görülmemiş olsa da Osmanlı yöneticilerinin bu konudaki temkinli tutumu aynı dikkati Steindachner için de gösterdikleri şeklinde yorumlanabilir.

Franz Steindachner'in Osmanlı yönetimi ile daha sık iletişimi 1893 tarihli dördüncü Doğu Akdeniz Keşif seferi ile başlamıştır. Daha sefer hazırlıkları sırasında 1893 yılı başlarında Selanik'e gelmiş olan Steindachner'in gümrükte beraberindeki kitaplara el konulmuştur. Ancak genel bir temkinlilik durumu ile el konulmuş olmalı ki herhangi bir sakıncalı durumu olmadığından dolayı yaşanan sorunda Osmanlı Devleti yönetimi bu durumun telafisi için eşdeğer bir çözüm önerisinde bulunmuştur (BOA, BEO, 134/10040, H. 16.06.1310/5 Ocak 1893). 1889 yılında projelendirilip 1890 yılında başlamış olan bu keşif 
seferlerinde güneydeki adalar ve çevresi dişında, Ege Denizi ve Marmara denizi henüz keşif seferi yapılmamış alan olarak kalmıştı. Bu araştırmalara devam edilebilmesi için yeni bir gemi tahsisine karar verilmiştir çünkü Osmanlı hükümeti, savaş gemisi olmasından dolayı Pola'nın Çanakkale'den geçişine izin vermeyi reddetmiştir. Karadeniz ile Akdeniz arasındaki su akıntısının belirlenmesi için Marmara Denizi araştırmaları özel bir öneme sahipti. Bu araştırma için Taurus adlı buharlı gemi tercih edilmiş fakat onun donanımının Pola adlı gemiden daha geri olmasından dolayı 1893 yılında Taurus'un donanımına zaman ayrılmıştır. Bu esnada keşif seferi Marmara Denizi yerine Çuha (Cerigo/Kithira) Adası, Küçük Çuha (Cerigotto/Antikithira) Adası ve Milo/Milos Adası sularının diplerindeki fauna (hayvan varlığı) ve Ege Denizinin oşinografisi üzerine yoğunlaşmıştır. Pola ile 16 Temmuz 1893'te başlayan ve 5 Ekim 1893 tarihinde Pula limanında biten son Akdeniz Açık Deniz Keşif seferi, yaşanan olumsuz hava koşullarından ötürü Steindachner'in istediği gibi verimli bir araştırma gezisi olmamıştır. Bu gezide dikkat çeken bir ayrıntı da mevcuttur. Zira bu dönemde İstanbul ve Gelibolu'da yaşanan kolera salgınından dolayı Pola'nın Delos limanına girmesine izin verilmemiştir (Schefbeck, 1996, s. 14-15).

1893 yılındaki Avusturya Dördüncü Açık Deniz Keşif seferinde Steindachner, Rodos ve Fethiye'den sonra İzmid ve Eskişehir'de, daha sonra İstanbul üzerinden gittiği Edirne, Dedeağaç, Selanik, Üsküp ve Prizren'de araştırmalar yapmıştır (Kähsbauer, 1959, s. 6). Bu keşif seferi kapsamında 1893 Eylül'ünde Terkos gölüne geldiği bilinen Steindachner'in yine çalışmalarına engel olunmaması yolunda Osmanlı Devleti ilgili kurumlarına talimat vermiştir (BOA, DH.MKT., 131/11, 01.03.1311/12 Eylül 1893; BOA, BEO, 280/20955, H. 13.03.1311/24 Eylül 1893). Ancak Temmuz ayındaki belgede Edirne, Selanik, Manastır, Kosova ve İşkodra vilayetlerinde balık ve böcekler ile ilgili araştırma yapacak olan Franz Steindachner'in kontrol altında tutulmasına dair bir belgenin mevcudiyeti (BOA, DH.MKT., 88/28, H. 03.01.1311/17 Temmuz 1893), Osmanlı Devleti yetkililerinin tedbiri elden bırakmadığı şeklinde de yorumlanabilir. Bu örneklerden hareketle, Franz Steindachner'in genel olarak bu araştırma gezilerinde Osmanlı Devleti yönetiminin herhangi bir engeli ile karşılaşmadığı söylenebilir (BOA, DH.MKT., 244/55, 28.11.1311/2 Haziran 1894).

Bu dönemde, Steindachner katılamamış olsa da, Taurus ile çıkılan ve Steindachner'in çalışmalarını takip ettiği Marmara Denizi keşif seferi de gerçekleşmiştir. Marmara Denizi için istenen izinin şartları ancak 1894'te yerine getirilebilmiştir. 22 Mayıs 1894 'te İstanbul'da başlayıp 30 Mayıs 1894'te Çanakkale'de biten bu keşif seferinde bilim adamı olarak sadece kimya alanında uzman olan Konrad Natterer bulunmuştur. Franz Steindachner'in dahil olduğu bir başka gelişme ise 11 Kasım 1893 tarihinde Donanmanın önerisiyle 1894'te Adriyatik Denizinde deniz biyolojisi alanında keşif seferinin yapılması olmuştur. Bilimler Akademisi bu iş için Franz Steindachner ve Friedrich Siebenrock'u (1853-1925) görevlendirmiştir. 31 Mayıs 1894 tarihinden 2 Ağustos 1894 tarihine kadar Adriyatik ve İyon Denizi kuzeyinde deniz biyolojisi ile ilgili araştırmalar yapılmıştır (Schefbeck, 1996, s. 16).

Osmanlı Devleti arşiv belgeleri arasında 4 Eylül 1894 tarihli arşiv kaydı Dr. Franz Steindachner'in bu seferi hakkında mühim bilgiler içermektedir. Üsküb'den alınan bilgilere göre İşkodra'dan Prizren'e gitmiş olan Dr. Franz Steindachner burada Avusturya misafirhanesi olarak adlandırılan bir konutta kalmış ve Bülbül deresi civarında nehirlerden balık ve benzeri küçük hayvan numuneleri toplamıştır (BOA, DH.ŞFR., 168/72, R. 23.06.1310/4 Eylül 1894). Bundan 5 gün kadar sonra ise Steindachner'in Selanik'e gelmiş olduğu yine Osmanlı Devleti arşiv belgelerinden anlaşılmaktadır. Kosova valisi tarafından 
Dahiliye Nezaretine gönderilen şifre telgrafta bulunan, Steindachner ve ahvali için 'nazar-1 teftişe tutulması emr olunan' ifadesi Osmanlı yetkililerinin bu keşif seferlerine verdiği önemi göstermesi açısından önemlidir (BOA, DH.ŞFR., 168/89, R. 28.06.1310/9 Eylül 1894). Bu önem elbette sadece bilimsel açıdan değil aynı zamanda kişilerin hal ve hareketlerinin takibi konusundadır.

Steindachner'in araştırmalarında Osmanlı Devleti'nin engelleyici olmadığı gibi kolaylaştıran bir tutumunun olduğunun bir başka örneği daha mevcuttur. 11 Ekim 1894 tarihli belgede Osmanlı yetkililerinin Franz Steindachner'ın Edirne, Manastır, Kosova, Yanya ve İşkodra'daki araştırmalarında toplamış olduğu üç sandık balık ve böceklerin açılarak gönderilmesini istedikleri anlaşılmaktadır (BOA, BEO, 492/36887, H. 10.04.1312/11 Ekim 1894). Ancak Avusturya konsolosunun çabalarıla birkaç gün içinde yeni bir karar alınması sağlanmıştır. Hariciye Nezaret-i Celilesine yazılmış olan bu yeni karara göre balık ve böceklerin bozulma ihtimali ve sandıkların ithal değil ihraç edilmek istenmesi gibi nedenlerden ötürü aynı sandıkların, İşkodra'daki Avusturya konsolosu aracıllı̆ııla vergisiz ve denetimsiz olarak Viyana Müzesine gönderilmek üzere Osmanlı Devleti sınırları dışına çıarılmasına izin verilmiştir (BOA, HR.TH., 148/23, M. 17.10.1894). Bu süreçte yaşananlar Franz Steindachner'ın çalışmalarında Avusturya-Macaristan İmparatorluğu'nun desteğine de dayanarak sahip olduğu güveni ve serbestliğini göstermektedir.

Avusturya-Macaristan İmparatorluğu 1890'1 y yılların ikinci yarısında, Doğu Akdeniz'deki keşif seferlerinin sınırlarını genişletme kararını uygulamaya geçmiştir. 19. yüzyıl ikinci yarısından itibaren ulaşım ve stratejik önemi artan Kızıl Deniz ve civarındaki bölge, oşinografi çalışma alanı kapsamında ayrıntılı olarak ele alınmak istenmiştir. Bu kapsamda Ekim 1895-Mayıs 1896 tarihleri arasında Steindachner, Kraliyet Bilimler Akademisi ile birlikte Birinci Kızıl Deniz Keşif seferini gerçekleştirmiştir (Kähsbauer, 1959, 26 Ağustos, s. 7).

Avusturya-Macaristan İmparatorluğu'nun Açı Deniz Keşif seferleri planının Adriyatik Denizi ve Akdeniz'in bir bölümünden sonraki bu yeni aşaması ilki ile bağlantılı devam etmiştir. Donanma'nın 24 Eylül 1894'te hazırladığı önerinin Kraliyet Bilimler Akademisi'ne sunulmasından sonra 6 Ekim 1894'te Kızıl Deniz'i kapsayan ilk keşif seferi başlamıştır. Araştırma alanı olarak iki bölge belirlenmiştir. Bölgelerden birisi Süveyş ve Akabe körfezlerini kapsamak üzere Kızıl Deniz'in kuzeyidir, diğeri ise Kızıl Deniz'in Babülmendeb Boğazı ve Cidde arasındaki bölgeyi kapsayan güneyidir. Franz Steindachner başında yer yer aldığı bu keşif seferinin bilim adamları arasında Friedrich Siebenrock, Konrad Natterer ve Josef Luksch yer almıştır. 6 Ekim 1895 ile 18 Mayıs 1896 tarihleri arasındaki bu yaklaşık 7 aylık keşif seferi, meteorolojik araştırmalarla beraber oşinografi alanında da Kızıl Deniz'de incelemelere fırsat tanımıştır (Schefbeck, 1996, s. 17-18). Bu seyahat süresince Kızıl Deniz dışında güzergâh üzerinde olan Filistin, Suriye, Anadolu ve Kuzey Yunanistan topraklarında da araştırmalar yapılmıştır (Kähsbauer, 1959, s. 7).

İkinci Kızıl Deniz Keşif seferi 4 Eylül 1897'den 24 Mart 1898'e kadar yaklaşık 6,5 ay devam etmiştir. Steindachner bu keşif seferinde ancak Aralık 1897 tarihine kadar yaklaşık 4 ay kadar kalabilmiştir. Avusturya Kraliyet Doğa Tarihi Müzesi müdürlüğüne atanmış olduğu için Viyana'ya dönmüştür. 1897'de Viyana Zooloji-Botanik Derneği onur üyeliğine seçilen Franz Steindachner, 15 Şubat 1898'de Avusturya Kraliyet Doğa Tarihi Müzesi müdürü olarak göreve başlamış ve aynı dönemde Kraliyet Konsey Üyesi olmuştur (Kähsbauer, 1959, s. 7, 9). Keşif seferinin kalan süresinde bu görevi Friedrich Siebenrock ve 
Josef Luksch devam ettirmişlerdir. Steindachner bu keşif seferinde kendisi fiilen bulunamasa da Kızıl Deniz derinliklerinin faunasının araştırılmasını istemiş ve bu konuda çalışılmıştır. Kızıl Deniz Keşif seferleri sadece Kraliyet Bilimler Akademisi değil Donanma için de araştırmalar yapılmasını sağlamıştır (Schefbeck, 1996, s. 19).

Franz Steindachner'in 1890'lı yılların başlarından itibaren Osmanlı Devleti'nin Balkanlar bölgesini de içine alan bölgede başlayan araştırma gezileri 1898 yılında Avusturya Kraliyet Doğa Tarihi Müzesi müdürlüğü görevinin yoğunluğu nedeniyle kesintiye uğramıştır. Bunun etkisi yayın faaliyetlerinde de görülmüştür. Kızıl Deniz Keşif seferi ile ilgili sadece iki yayın yapmış (Stagl, Sattmann, Dworschak, 1996, s. 29-41) olması da bundan dolayı olmalıdır. Ancak Steindachner dışında, Avusturya Bilimler Akademisi başka üyelerinin Osmanlı Devleti topraklarında zoolojiden jeolojiye kadar farklı alanlardaki araştırmaları devam etmiştir. Osmanlı Devleti yönetiminin bu dönemde bu araştırmalara karşı genel olarak kolaylaştıııcı tutumu devam etmiştir. Osmanlı Devleti tarafından dikkatle takip edilmeye devam eden bu araştırmalardan bir tanesi Avusturya Kraliyet Doğa Tarihi Müzesi görevlisi Doktor Arnold Penter ve hayvanat ve nebatat uzmanı Mösyö Nemyeriç Zidbaver'in tertip etmiş oldukları araştırmalardır. Hayvanat ve nebatat üzerine araştırmalarda bulunmak maksadıyla 1902 yılında Ankara ve Konya vilayetlerinde seyahat edecek olan Penter ve Zidbaver, yapacakları araştırmalarda kendilerine kolaylık sağlanması talebine Osmanlı Devleti olumlu yanıt vermiştir (BOA, HR.TH., 266/42, M. 28.03.1902; BOA, İ..HR., 376/11, H. 29.12.1319/8 Nisan 1902). Bu belgeler, Avusturya-Macaristan İmparatorluğu'nun Osmanlı Devleti topraklarındaki araştırma alanının genişliğini göstermesi açısından önemlidir.

Franz Steindachner'ın Osmanlı Devleti topraklarında doğa bilimleri alanında araştırma yaptığı dönemlerden sonra da gerek yurttaşı gerek başka Avrupa ülkelerinin bilim adamlarının da benzer amaçla Osmanlı topraklarında seyahat ettiği bilinmektedir. Bunlardan bir tanesi 1902 yılı sonlarında Urfa'da bulunan heyet-i fenniye müfettişi Almanyalı Franç Akart olarak kayda geçmiş olan araştırmacıdır. Bu araştırmacının bölge halkı ile yaşadığı sorun onun bilimsel faaliyetleri ile ilgili olmayıp asayiş sorunudur. Olay, Urfa'da bu heyetin yoldan geçtiği sırada süvari binbaşısı Mustafa Efendinin çocuğunun arabaya zarar verme durumu üzerine mahkemeye taşınmıştır (BOA, DH.MKT., 909/38, H. 02.09.1322/10 Kasım 1904) ${ }^{1}$. Osmanlı arşiv belgelerinden edinilen bilgilere dayanarak, Franz Steindachner'ın bölgede yaptığı araştırmalar boyunca bu tür olaylara karışmamış ve hakkındaki arşiv belgelerinin sadece araştırmaları ile ilgili olmasının, hakkındaki vefayat yazılarında da değinildiği gibi, onun işine odaklanmış hayatının bir göstergesidir.

Franz Steindachner ve Osmanlı Devleti Topraklarındaki Araştırmalarında Bilime Katkıları

İhtiyoloji alanında 200'den fazla, herpetoloji alanında 52 kadar yayını olan Franz Steindachner, yeni ve fosil olmak üzere 1000 'den fazla balık türü ile 150 'den fazla amfibi ve sürüngen türü adını belirlemiştir. Franz Steindachner'in (Kähsbauer, 1959, s. 13-21; "Steindachner, Franz", 2013) 1891-1898 yılları arasında Osmanlı Devleti topraklarındaki araştırmalarında da bu tür etkinlikleri olmuştur. Bugün için Türkiye'de ihtiyoloji alanındaki çalışmalarda Franz Steindachner ile ilgili bilgiler, adını verdiği balık türleri ile sınırlı kalmıştır denilebilir. Bu çalışmanın konusu Steindachner'in ihtiyoloji alanına katkıları

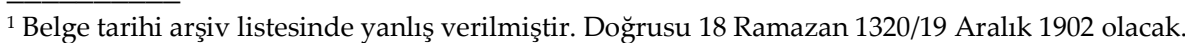


olmayıp, bu katkıları oluştururken Osmanlı Devleti topraklarındaki araştırmalarının tarihsel seyrini ortaya koymaktır. Bu bağlamda, Steindachner'in zooloji amaçlı Osmanlı coğrafyasındaki seyahatleri Osmanlı Devleti yetkilileri tarafından nasıl karşılanmış, ne gibi kolaylaştırıcı veya zorlaştırıcı muameleye maruz bırakılmış olduğu sorularına yanıtları aranmıştır. Ancak bununla beraber Steindachner'in Osmanlı Devleti topraklarında yaptığı araştırmalar sırasındaki keşifleri de önemlidir. 1891-1898 yılları arasındaki keşif seferleri kapsamında kısmi zamanlı olarak Balkanlar ve Anadolu topraklarında bulunmuş olan Franz Steindachner'in bu dönemde araştırma yaptığı Balkanlar ve Anadolu coğrafyasının ihtiyoloji alanına koyduğu katkı günümüzde de geçerliliğini devam ettirmektedir. Osmanlı Devleti'nde balıklar ile ilgili yayınlanan en eski eserin ancak 1915 yılında basıldığ (Deveciyan, 2019) düşünülürse Franz Steindachner'in çalışmalarının değeri daha anlaşlır olacaktır. Steindachner tarafından belirlenmiş türler arasında Akdeniz bölgesine ait en çok bilinen türler arasında Siraz Balığı (Capoeta sieboldii) (Steindachner, 1864), (Yazıcıŏglu, 2011), sarıkuyruk istavrit balığı (Trachurus mediterraneus (Steindachner, 1868) (Demirel, 2010) bulunmaktadır. Onun bölgede fiilen bulunduğu 1891-1898 yılları arasında Türkiye'de yaptığı araştırmalarda bu bölge içerisinde tür adını koymuş olmasından dolayı kendi adıyla birlikte anılan endemik türler ve bölgeleri şunlardır:

Kara/Likya semenderi, (Lyciasalamandra luschani) (Steindachner, 1891) (Karış, Göçmen, Mermer, 2015, s. 107-136),

Barbus escherichii (Steindachner, 1897), Karadeniz,

İnci balığı, Alburnus escherichii (Steindachner, 1897), Karadeniz, Sakarya ve Kizılırmak nehirleri,

Çamur/Çöpçü balığı, (Oxynoemacheilus angorae) (Steindachner, 1897), Orta ve kuzeybatı Anadolu (Çiçek, Fricke, Sungur, 2018, s. 5, 9, 18).

\section{Avusturya Kraliyet Doğa Tarihi Müzesi Müdürlüğü Sonrası Faaliyetleri}

Steindachner 15 Şubat 1898'de Avusturya Kraliyet Doğa Tarihi Müdürü olarak göreve başladıktan sonra iş yoğunluğu nedeniyle keşif seferlerini bir süreliğine aksatmıştır. Bu seferlere tekrar yoğunluk vermeye başlayan Franz Steindachner Ocak 1902 tarihinde Sibirya balıkları ile ilgili araştırma içir Petersburg'a giderek orada müzeyi ziyaret etmiştir (Kähsbauer, 1959, s. 7).

Anadolu ve Balkanlardaki keşif gezileri sona ermiş olan Franz Steindachner'in 1903 yılında Kraliyet Bilimler Akademisinin desteği ile Brezilya'ya yaptığı gezi kendisinin son keşif seyahati olmuştur. Aynı yıl California Bilimler Akademisi Onur Üyeliğine de seçilen Steindachner 1905'te Viyana'da Uluslararası Balıkçılık Kongresi Başkanlığı görevini de icra etmiştir (Kähsbauer, 1959, s. 7, 9).

I. Dünya Savaşı sonrası Avusturya-Macaristan İmparatorluğu'nun yıkılması Avusturya'daki bilimsel çalışmaları olduğu gibi Steindachner'in hayatını da olumsuz etkilemiştir. Emekli olmak durumunda kalan Steindachner'e Eğitim Bakanlığı sahip çıkmış ve Eğitim Bakanlığı emeklisi olarak hayatına devam etmesi kararlaştırılmıştır. Ancak yazışmalar vb bürokratik işlemlerin uzaması sonucu ancak 1919 yılı ortalarında emekli olabilmiştir. Emekliliğinde Avusturya Kraliyet Doğa Tarihi Müzesinin bitişiğindeki 4 odalı bölümde kiracı olarak kalmaya devam etme isteği kabul edilmişse de Steindachner'in toplam emeklilik süresi sadece 10 hafta kadar devam edebilmiştir ("The Herpetological

SEFAD, 2020; (44): 487-508 
Collection", (t.y.)). 10 Aralık 1919'da 86 yaşında zatürreden dolayı vefat etmiştir (Kähsbauer, 1959, s. 10).

Zoolog ve ihtiyolog olan Franz Steindachner 85 yıllık ömrünün yaklaşık dörtte üçünü ihtiyoloji araştırmalarına adamıştır. Hakkında yazılan iki vefayat yazısı (Wiley, 1921, s. 486; Starr, 1921, s. 68), onun kişiliği kadar meslek hayatı ile ilgili açıklamaları da içermektedir.

1878 ve 1898 yıllarında 20 yıl ara ile ziyaret ettiği Steindachner'in oldukça sade bir hayat sürdügünü söyleyen Amerikalı kimya uzmanı Dr. Harvey Washington Wiley (18441930), Steindachner'in günlük işlerinde yardımcısının bekar kız kardeşi olduğunu ifade etmiş̧ir. Wiley vefayat yazısında bilimsel çalışmalarının değeri zaten bilinen Steindachner'in bilimsel niteliğinden ziyade kişiliği ve insanlar tarafından saygı ve sevgi ile yad edildiği üzerinde durmanın daha anlamlı olduğunu belirtmiştir. 1898'de asaleten atandığı dönemde Avusturya Kraliyet Doğa Tarihi Müzesi Müdürü (Feigl, 2016, s. 209) Steindachner'i son ziyaretinde kendisine Harvard'da birlikte çalıştığı insanların mektubunu götürdüğünden bahseden Wiley, Steindachner'in kaybının arkadaş çevresi için, bilim çevresi için olduğundan daha ağır olduğunu vurgulamıştır (Wiley, 1921, s. 486). 1887 yılında Harici Üye olarak seçildiği Londra'daki Linnean Topluluğu tarafından 1921 yılında yayımlanan vefayat yazısı da Steindachner'in ömrünün sonuna kadar, araştırmalarını tartışmak için genç meslektaşlarıyla iletişim halinde olan değerli bir bilim adamı olduğunu belirtmiştir (Anonim, 1921, s. 55-56).

\section{SONUÇ}

Keşifler çağı olarak da adlandırılan 19. yüzyıl, Avusturya-Macaristan İmparatorluğu için de önemli değişimlerin yaşandığı bir çağ olmuştur. Yüzyıl boyunca siyasi yapılanma şekli değişmiş, önce Avusturya İmparatorluğu (1806), sonra Avusturya-Macaristan İmparatorluğu (1867) olmuş, yüzyılın sonunda ise siyasi yapılanma şeklinin tamamen değişeceği sürece girmiş ve I. Dünya Savaşı sonrası 1918'de İmparatorluk yıkılmıştır. Fakat aynı dönemde aynı Avusturya-Macaristan İmparatorluğu'nun bir başka özelliği farklı bir tablo ortaya koymuştur. Özellikle doğa bilimlerindeki çalışmalarıyla keşifler çağı olarak adlandırılan dönemin öncü devletlerinden birisi olmuştur. Avusturya-Macaristan İmparatorluğu 1815-1835 arasında Brezilya yağmur ormanlarında başlayan keşif seferlerine olan desteğini 1857-1859 yılları arasında Novara adlı gemi ile dünya ölçeğine taşımıştır. Avusturya-Macaristan İmparatorluğu'nun 1872-1874 yılları arasındaki Kuzey Kutbu Keşif seferinden sonra desteklediği 1890-1898 yılları arasındaki Açı Deniz Keşif seferleri, zoolog Franz Steindachner'in adının etkin isimler arasında olmaya başlamasını sağlamıştır. Steindachner bu Doğu Akdeniz ve Kızıl Deniz Keşif seferleri esnasında Osmanlı Devleti topraklarında da araştırma yapma fırsatı bulmuştur.

19. yüzyıl Osmanlı Devleti için de siyasi yapılanmasının değişim geçirdiği bir dönem olmuştur. Ancak Avusturya-Macaristan İmparatorluğu ile arasındaki önemli farklardan bir tanesi de keşifler çağı denen dönemde edindiği yer olmuştur. Osmanlı Devleti için yenileşme dönemi olarak da adlandırılabilen bu süreçte Osmanlı Devleti'nde de Brezilya veya Yemen gibi yerlere keşif seferleri gerçekleştirenler olmuştur. Ancak bu seferlerin sayısı az olduğu gibi bilime katkıları açısından da cılız kalmıştır. Bu durumun önemli nedeni, siyasi, iktisadi ve sair sebeplerden dolayı bilimsel keşifleri desteklemenin bir devlet politikası olarak gündeme alınmamış olmasıdır. 
Viyana'da Avusturya Kraliyet Doğa Tarihi Müzesi müdürlüğü görevi ile tanınan zoolog Franz Steindachner'in bilimsel etkinliği Avusturya-Macaristan İmparatorluğu'nun Doğu Akdeniz ve Kızıl Deniz Keşif seferlerinde daha görünür olmuştur. Bu keşif seferleri 1890-1898 yılları arasında gerçekleşmiştir. Bu keşif seferleri kapsamında Steindachner'in Balkanlar ve Anadolu topraklarında bulunduğu bilinmektedir. Bu araştırmaları süresince Osmanlı Devleti yetkilileri, kendi topraklarında bir yabancı tarafından yapılan bu araştırmaları yönlendirmekte her zaman başarılı olamamışlarsa da sıkı takip altında tutmak için gayret göstermişlerdir. Bu tutum elbette sadece Steindachner ile ilgili değil, genel bir uygulama idi. Bu sıkı takibin nedeni ne yapıldığının bilinmesi için olsa da kimi zaman işin boyutunu anlamayan görevlilerin olduğu da belgelerden anlaşılmaktadır. Çünkü bu dönemde Osmanlı Devleti'nde henüz doğa bilimleri konusunda yeterli bilgi birikimi oluşturulmamış ve bu konuda farkındalık gelişmemişti.

Franz Steindachner'in Osmanlı Devleti topraklarında yaptığı araştırmalar 1891-19898 yıllarını kapsamaktadır. Bu dönemde ağırlıklı olarak Balkanlarda araştırma yapmış olduğu görülmektedir. Selanik, Yanya, İşkodra, Manastır Balkanlarda araştırma yapmak için bulunduğu yerlerden bazılarıdır. Bu araştırmalarında ihtiyoloji, ağırlıklı çalışma alanı olmuştur. Özellikle nehir ve göllerde balık ve diğer canlıların çeşitliliği hakkında çalışmıştır. $\mathrm{Bu}$ çalışmaları sonucunda Osmanlı Devleti topraklarının ilgili kısımlarının ihtiyoloji alanındaki varlığı hakkında bilgi ortaya konmuştur. Avusturya-Macaristan İmparatorluğu'nun desteğinin Franz Steindachner'in araştırmaları sırasında karşılaşabileceği sorunları çözmede etkili olduğu da yine arşiv belgelerine yansımıştır.

85 yıllık ömrünün neredeyse dörtte üçünü ihtiyoloji çalışmalarına adamış olan Avusturya Kraliyet Doğa Tarihi Müzesi müdürü Franz Steindachner, ihtiyoloji alanında 200 'den fazla ve herpetoloji alanında 52 kadar tanımlama yapmıştır. Türkiye sularında da örnekleri bulunan türlere ad verdiği gibi Türkiye coğrafyasındaki endemik türler arasında da ad verdikleri olmuştur.

\section{SUMMARY}

The 19th century is a period when discoveries are intense in the natural sciences. Scientific researches in oceanography, which can be defined as the integration of other natural sciences with marine research, resulted that oceanography became a separate branch of science in this period. In the oceanographic studies, the Austro-Hungarian Empire became one of the leading states. Zoologist Franz Steindachner is a famous scientist who took part in the oceanographic studies supported by different institutions of the Austro-Hungarian Empire. It is known that Steindachner, who participated in the expeditions in the Eastern Mediterranean and the Red Sea, also made researches in the territory of the Ottoman State.

Among the studies in the current literature review, it is possible to find information about the historical development of the marine science (oceanography) branch. However, it is also possible to access information about Franz Steindachner's contribution to the expeditions, especially in the Eastern Mediterranean and the Red Sea. However, there is no special study on the research initiatives and the results of these researches in the territory of the Ottoman State, i.e. in the Balkans and Anatolia.

In this study, there are two important publications used among the sources containing information about Franz Steindachner's life and his scientific studies. Originally published by Günther Schefbeck in 1996, "The Austro-Hungarian Deep-Sea Expeditions", is a short 
history of the oceanography discipline, as well as Franz Steindachner's contributions to the oceanography discipline, and his research in the Eastern Mediterranean and the Red Sea. This paper is an important work that reveals the role of Franz Steindachner. However, the most important shortcoming of this work in the context of this article is that it contains incomplete and sometimes incorrect evaluations in relation to the Ottoman State. The second important publication is titled Biographisches, Intendant Dr. Franz Steindachner, sein Leben und Werk, in the Yearbook of the Natural History Museum written in 1959 by von Paul Kähsbauer on the 40th anniversary of Franz Steindachner's death. In this publication, it is seen that the life and scientific studies of Steindachner are the most elaborated among the sources reached. However, the most important shortcoming of this study is how the Ottoman State directed and influenced Franz Steindachner's works.

The most important resource group of this article is the archival records of the Ottoman Empire on the subject. It is known that Franz Steindachner was in the Balkans and Anatolia during the 1890s. Among the archive documents that can be accessed, the oldest date of the documents, which are directly related to Steindachner's researches in the Balkans and Anatolia or to evaluate his research in these regions, belongs to 1891. The most recent document even indirectly related one that can be accessed, other than the documents concentrated in the 1890s, belongs to 1898 .

With this research, the studies of Zoologist Franz Steindachner in the Ottoman State and the approach of the Ottoman State officials to these studies will be presented in the time period that lasts about 10 years in the late 19th century. With this singular example, only some of the place of the Ottoman Empire in the age of discoveries will be revealed.

Makale Bilgileri

Etik Kurul Kararı:

Etik Kurul Kararından muaftır.

Katılımcı Rızası:

Katılımci Yok

Mali Destek:

Çalışma için herhangi bir kurum ve projeden mali destek alınmamıştır.

Çıkar Çatışması:

Çalışmada kişiler ve kurumlar arası çıkar çatışması bulunmamaktadır.

Telif Hakları:

Çalışmada kullanılan görsellerle ilgili telif hakkı sahiplerinden gerekli izinler alınmıştır.

Article Information

Ethics Committee Approval: Exempt from the Ethics Committee Decision.

Informed Consent: No participant

Financial Support: No financial support from any institution or project.

Conflict of Interest: No conflict of interest.

Copyrights:

The required permissions have been obtained from the copyright holders for the images and photos used in the study. 


\section{KAYNAKÇA}

\section{Arşiv Belgeleri}

T.C. Cumhurbaşkanlığı Devlet Arşivleri Başkanlığı, Başkanlık Osmanlı Arşivi (BOA)

BOA, Dahiliye Nezareti Mektubi Kalemi (DH.MKT.), 1445/104, H. 22.12.1304 (11 Eylül 1887).

BOA, Maarif Nezareti Mektubi Kalemi (MH.MKT.), 1728/16, H. 13.10.1307 (2 Haziran 1890).

BOA, Dahiliye Nezareti Mektubi Kalemi (DH.MKT.), 1979/58, H. 03.01.1310 (28 Temmuz 1892).

BOA, Bâb-1 Âli Evrak Odası (BEO), 134/10040, H. 16.06.1310 (5 Ocak 1893).

BOA, Dahiliye Nezareti Mektubi Kalemi (DH.MKT.), 88/28, H. 03.01.1311 (17 Temmuz 1893).

BOA, Dahiliye Nezareti Mektubi Kalemi (DH.MKT.), 131/11, 01.03.1311 (12 Eylül 1893).

BOA, Bâb-1 Âli Evrak Odası (BEO), 280/20955, H. 13.03.1311 (24 Eylül 1893).

BOA, Dahiliye Nezareti Mektubi Kalemi (DH.MKT.), 244/55, 28.11 .1311 (2 Haziran 1894).

BOA, Dahiliye Nezareti Şifre Kalemi (DH.ŞFR.), 168/72, R. 23.06.1310 (4 Eylül 1894).

BOA, Dahiliye Nezareti Şifre Kalemi (DH.ŞFR.), 168/89, R. 28.06.1310 (9 Eylül 1894).

BOA, Bâb-1 Âli Evrak Odası (BEO), 492/36887, H. 10.04.1312 (11 Ekim 1894).

BOA, Hariciye Nezareti Tahrirat (HR.TH.), 148/23, M. 17.10.1894.

BOA, Hariciye Nezareti Tahrirat (HR.TH.), 266/42, M. 28.03.1902.

BOA, İrade Hariciye (İ..HR.), 376/11, H. 29.12.1319 (8 Nisan 1902).

BOA, Dahiliye Nezareti Mektubi Kalemi (DH.MKT.), 909/38, H. 02.09.1322 (10 Kasım 1904) (Belge tarihi arşiv listesinde yanlış verilmiştir. Doğrusu 18 Ramazan 1320-19 Aralık 1902 olacak).

\section{Kitap, Makale ve Diğer Eserler}

Annual Report of The Board of Regents of the Smithsonian Institution. (1898). Washington: Government Printing Office.

Anonim. (1921). Dr. Franz Steindachner. Proceedings of Linnean Society of London, 133, 55-56.

Asiltürk, B. (2009, Kış). Edebiyatın kaynağı olarak seyahatnameler. Turkish Studies, International Periodical for the Languages and History of Turkish or Turkic, 4(1-I), 911-995.

Çiçek, E., Fricke, R., Sungur, S. ve Eagderi, S. (2018). Endemic freschwater fishes of Turkey. FishTaxa, 3(4), 1-39.

Demirel, N. (2010). Kuzeydoğu Marmara Denizi'nde Sarıkuyruk İstavrit balığının (Trachurus mediterraneus) (Steindachner, 1868) üreme biyolojisi (Doktora tezi). Erişim adresi: https://tez.yok.gov.tr/UlusalTezMerkezi/giris.jsp.

Deveciyan, K. (2019). Türkiye'de balık ve balıkçıllk. (E. Üyepazarı Çev.) İstanbul: Aras yayıncilik.

Doktor İbrahim Abdüsselam Paşa, Yemen seyahatnamesi ve bitkisel coğrafyası. (2008). (Ergin Yıldızoğlu Yay. haz.). İstanbul: Pan yayıncılık.

Elmacı, İ. (2017). Osmanlı Türkiyesinde bilim akademisi kurma girişimleri ve deney. Osmanlı Bilimi Araştırmaları, 18(2), 77-92.

Erbaş, F. (2016, Güz). 19. yüzyıl Doğu Akdeniz donanma mücadelesinde öne çıkan devletler ve faktörler. FSM İlmi Araştırmalar İnsan ve Toplum Bilimleri Dergisi, 8, 133-158.

SEFAD, 2020; (44): 487-508 
ESSA Libraries Holdings in Oceanography and Marine Meteorology, 1710-1967 Volume 1Bibliography. (1969). Rockville: U.S. Department of Commerce, Environmental Science Services Administration.

Feest, C. (2013-2014a). Indigenous heritage Johann Natterer, Brazil and Austria. Archiv Weltmuseum Wien, 63-64, 1-3.

Feest, C. (2013-2014b). The Ethnographic collection of Johann Natterer and the other Austrian naturalists in Brazil A documentary history. Archiv Weltmuseum Wien, 63-64, 60-95.

Feigl, C. (Ed.). (2016). Academic showcases: The collections at the University of Vienna. Viyana: Böhlau.

Franz Steindachner 1834-1919, http://www.cotebleue.org/steindachner.html, (12 Nisan 2020).

İhsanoğlu, E. (1987. 3-5 Nisan). Modernleşme süreci içinde Osmanlı Devletinde ilmi ve mesleki cemiyetleşme hareketlerine genel bir bakış. E. İhsanoğlu (Yay. haz), Osmanlı İlmi ve Mesleki Cemiyetleri 1. Milli Türk Bilim Tarihi Sempozyumu (s. 1-32 içinde), İstanbul: Edebiyat Fakültesi Basımevi.

Jordan, D. S. (1921, 21 Ocak). Franz Steindachner. Science, 53(1360), 68.

Kähsbauer, Von P. (1959, 26 Ağustos). Biographisches, intendant Dr. Franz Steindachner, sein leben und werk. Viyana: Annal Naturhistorisches Museum. https://www.zobodat.at/biografien/ANNA_63_Steindachner_Franz_00010030_1959.pdf, (12 Nisan 2020).

Karıs, M., Göçmen, B. ve Mermer, A. (2015). Taxonomical and biological Ccomparison of the two Luschan's Lycian salamander, Lyciasalamandra luschani (Steindachner, 1891) (Urodela: Salamandridae) populations from Southwestern Anatolia. South-Western Journal of Horticulture, Biology and Environment, 6(2), 107-136.

Mühendis Faik, (1868). Seyâhatnâme-i Bahr-i Muhit: Ümit Burnu tarikiyle İstanbul-Basra seyâhati. İstanbul: Mekteb-i Bahriye-i Şahane Matbaası.

Nature. (1936, 16 May1s). 137, 808.

Novara expedition. (t.y.). http://www.amem.at/novara_expedition.html, (02 Mayıs 2020).

Organ, M. (2007, 10 Nisan). The Austrian imperial frigate SMS Novara 1843-99, A History of 'the most magnificiant vessel', https://documents.uow.edu.au/ morgan/novara1.htm. (03 Mayis 2020).

Salvini-Plawen, L., Svotjka, M. (2008). Fische, pertefakten und gedichte: Rudolf Kiner (18101869) - ein Streifzug durch sein leben und werk. Denisia, 24, Linz.

Schefbeck, G. (1996). The Austro-Hungarian deep-sea expeditions. F. Uiblein, J. Ott, M. Stachowitsch (Ed.), Deep-Sea and Extreme Shallow-Water Habitats: Affinities and Adaptations, Biosystematics and Ecology Series, 11, (1-27) içinde. Austrian Academy of Sciences Press.

Schimanski, J. ve Spring, U. (2009, Haziran). Explorers' bodies in Arctic mediascapes: Celebrating the return of the Austro-Hungarian Polar expedition in 1874. Acta Borealia, 26(1), 50-76.

Stagl, V. (2008). Steindacner, Franz (1834-1919) zoologe und ichtyologe. ÖBL (Österreichisches Biographisches Lexikon) 1850-1950, Cilt 13, Avusturya Bilimler Akademisi yayınları, 19572005, s. 164. https://biographien.ac.at/ID-0.3052994-1, (12 Nisan 2020). 
Stagl, V., Sattmann, H. ve Dworschak, P.C. (1996). The material of the Pola Red Sea expeditions (1895-1898) in the collections of the Natural History Museum in Vienna. F. Uiblein, J. Ott, M. Stachowitsch (Ed.), Deep-sea Extreme Shallow-water Affinities and Adaptations, Biosystematics and Ecology Sereies, 11, (s. 29-41) içinde. Austrian Academy of Sciences Press.

Steindachner, Franz. (2013). Neue Deutsche biographie, 25. https://www.deutschebiographie.de/sfz107509.html, (02 Mayıs 2020).

Svatek, P. (2014). The 'globe as an object of research. 19th and early 20th century globe studies in Vienna and Innsbruck. Globe Studies, 59-60, 112-124.

The herpetological collection. (t.y.). https://www.nhmwien.ac.at/en/research/1_zoology_vertebrates/herpetological_collection/history/the_her petological_collection, (03 Mayis 2020).

Wiley, H.W. (1921, 21 Ocak). Franz Steindachner. Science, 53(1377), 486.

Yazıcıoğlu, O. ve Yılmaz, M. (2011, İlkbahar). Hirfanlı Baraj Gölü'nde yaşayan Siraz balığı (Capoeta sieboldii) (Steindachner, 1864)'nin beslenme rejimi. Karadeniz Fen Bilimleri Dergisi. Y1l 2, 1(3), 62-73.

\section{EKLER}

Ek 1. Franz Steindachner'in Osmanlı Devleti Topraklarında Bulunduğu Yerler ve Yillar:

\section{0}

Çuha (Cerigo/Kithira), Libya sahilleri, Ras al Hilal, Bingazi

\section{1}

Girit, İskenderiye, Mısır sahilleri, Kuzey Ege kıyıları, Arnavutluk kıyıları, Pire limanı, Ayvasıl, Doyran, Amatovo, Ohri, Küçük Prespa (Ventrok) ve Prespa gölleri, Selanik, Manastır, Üsküb

\section{2}

Preveze, Yenice, Girit, İskenderiye, Nil deltası, Filistin, Suriye kıyıları, Kıbrıs kanalı, Karaman Denizi olarak adlandırdığı Anadolu'nun güneyi, Fethiye körfezi, Yanya vilayeti

1893

Çuha (Cerigo/Kithira) Adası, Küçük Çuha (Cerigotto/Antikithira) Adası, Milo/Milos Adası, Rodos, Fethiye, İzmid, Eskişehir, Edirne, Dedeağaç, Selanik, Üsküp, Prizren, Terkos gölü, Edirne, Selanik, Manastır, Kosova, İşkodra

\section{4}

Üsküb, Prizren, Selanik, Edirne, Manastır, Kosova, Yanya, İşkodra

\section{4-1896}

Süveyş ve Akabe körfezlerini kapsamak üzere Kızıl Deniz'in kuzeyi ile Babülmendeb Boğazı ve Cidde arasındaki güneyi, Filistin, Suriye, Anadolu 
Ek 2. Edirne, Selanik, Manastır, Kosova ve İşkodra vilayetlerinde balık ve böcekler ile ilgili araştırma yapacak olan Franz Steindachner' in kontrol altında tutulmasına dair belge:

BOA, DH.MKT., 88/28, H. 03.01.1311 (17 Temmuz 1893).

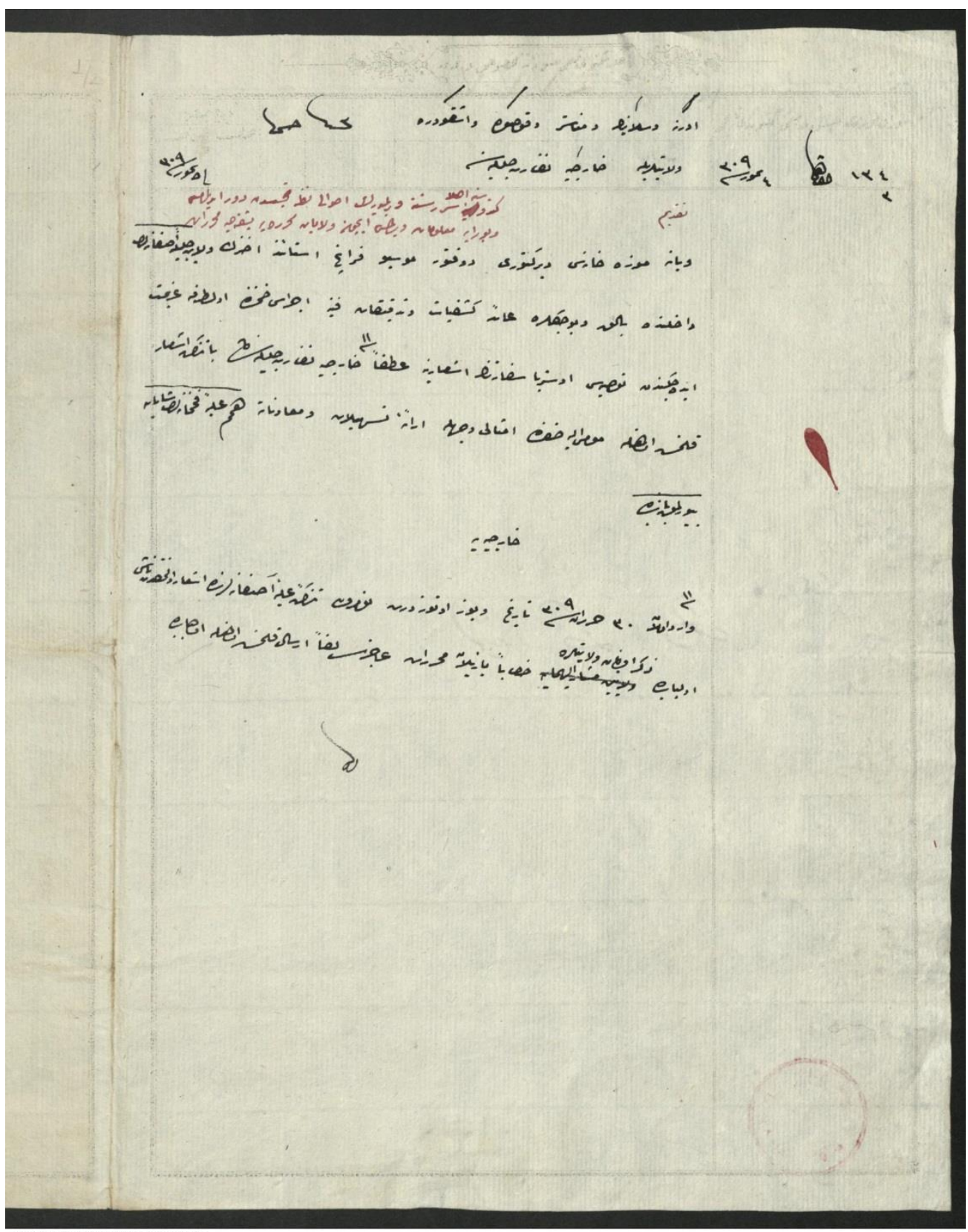

DH.MKT.00088.00028.001 
Ek 3.a. Franz Steindachner'ın Edirne, Manastır, Kosova, Yanya ve İşkodra'daki araştırmalarında toplamış olduğu üç sandık balık ve böceklerin açılarak gönderilmesi istenmesine dair belge:

BOA, BEO, 492/36887, H. 10.04.1312 (11 Ekim 1894)

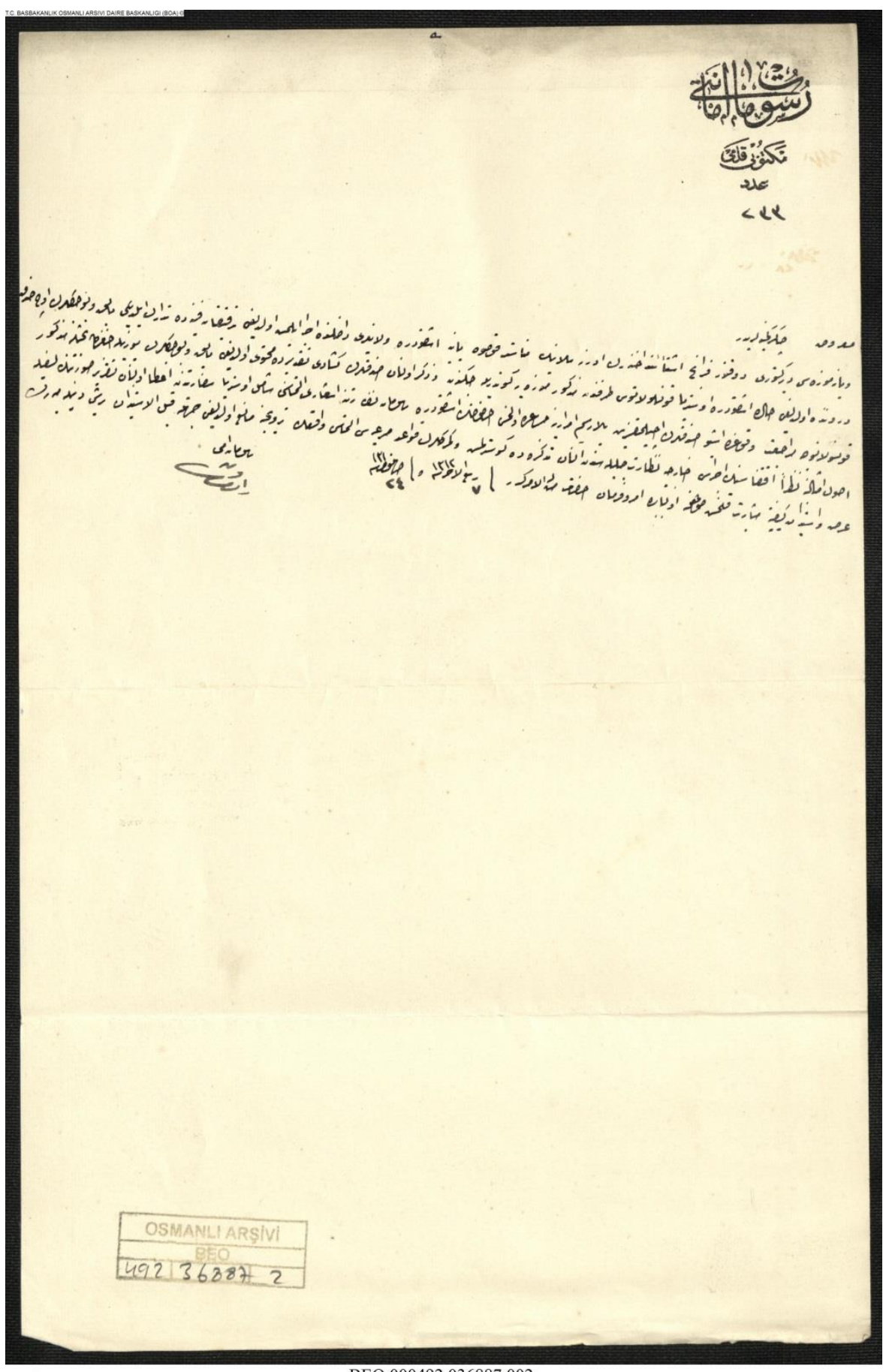

BEO.000492.036887.002 
Ek 3.b. Franz Steindachner'ın Edirne, Manastır, Kosova, Yanya ve İşkodra'daki araştırmalarında toplamış olduğu üç sandık balık ve böceklerin, İşkodra'daki Avusturya konsolosu aracilığıla vergisiz ve denetimsiz olarak Viyana Müzesine gönderilmek üzere Osmanlı Devleti sınırları dışına çıkarılmasının sağlandığına dair belge:

BOA, HR.TH., 148/23, M. 17.10.1894.

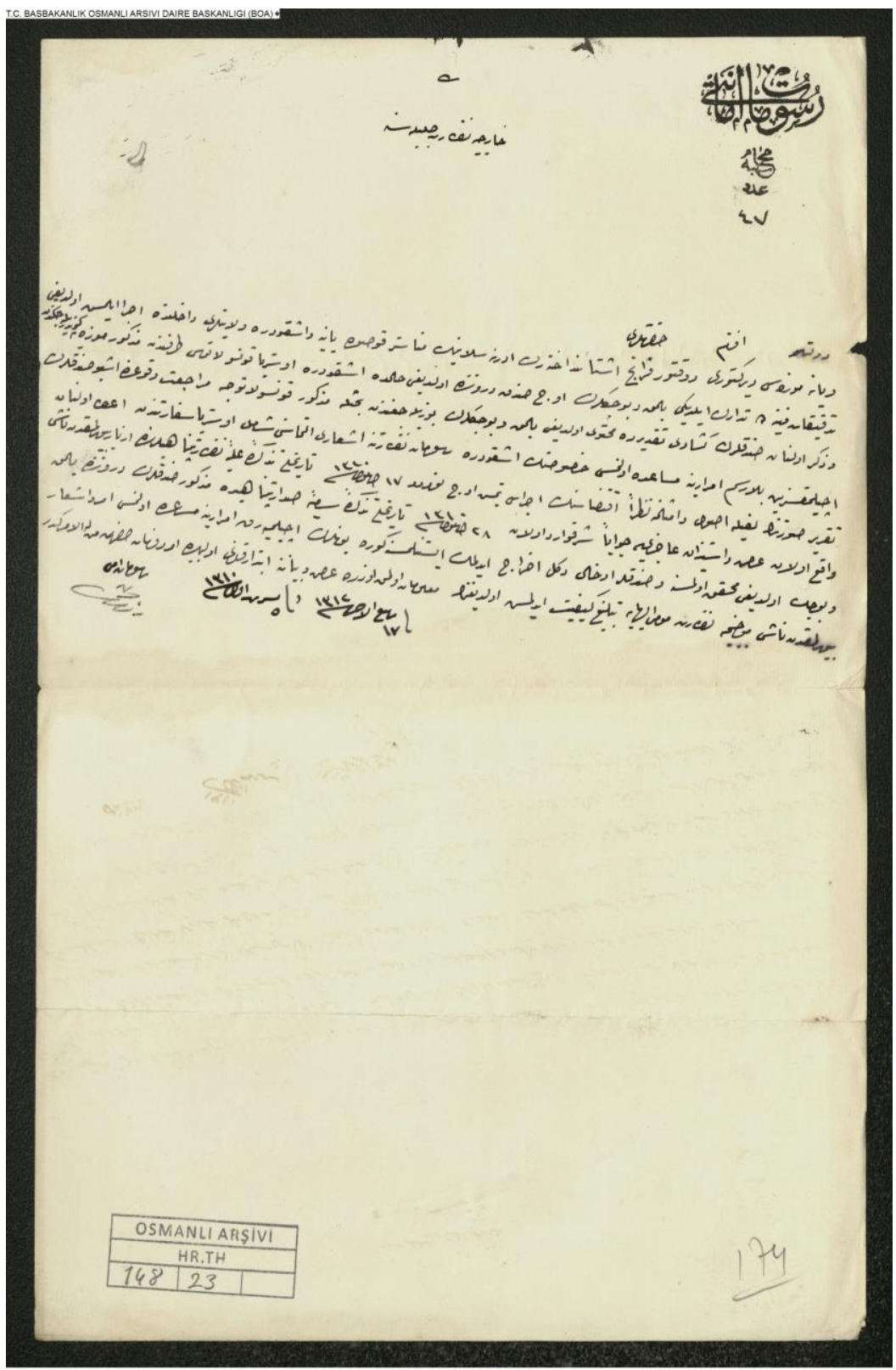

HR.TH.00148.00023.001 